\title{
Post harvest of pink ginger floral stems treated with silver thiosulphate, sucrose, and calcium
}

\author{
Antonio Tarciso C da Silva ${ }^{1}$; Vilma M Ferreira ${ }^{1}$; Érika SA Graciano ${ }^{1}$; Renan C de Souza ${ }^{1}$; João C de \\ Araújo Neto' ${ }^{1}$; Vivian Loges ${ }^{2}$ \\ ${ }^{1}$ UFAL-CECA, BR 104 Norte, km 85, 58100-000 Rio Largo-AL; ${ }^{2}$ UFRPE, Av. Dom Manoel de Medeiros, 52171-900 Recife-PE; \\ a.tarciso@gmail.com; vilmaferreira@ceca.ufal.br; erikagraciano@hotmail.com; renanibp@hotmail.com; jcanetto@bol.com.br; vloges@ \\ yahoo.com.br
}

\begin{abstract}
The Brazilian market of tropical flowers has been growing broadly with a strong participation of the Northeast Region, where the State of Alagoas stands out. Among the exporting tropical cut flowers, pink ginger (Alpinia purpurata (Vieill) K. Schum) has been one of the most promising species. Aiming at delaying senescence in floral stems of pink ginger, two laboratory experiments were carried out at the Agricultural Science Center of the Federal University of Alagoas. In the first experiment, three different exposure periods (30; 60, and 120 minutes) to silver thiosulphate $1 \mathrm{mM}$ were tested, followed or not by pulsing in a $20 \%$ sucrose solution, for 12 hours. In the second experiment, we evaluated the effect of adding calcium sulphate 50 and $100 \mathrm{mM}$, sodium silicate 1.25 and $2.5 \mathrm{mM}$, and the combination of calcium sulphate $50 \mathrm{mM}+$ sodium silicate $1.25 \mathrm{mM}$ on the hydric status and longevity of floral stems. In both experiments, the control treatment consisted of keeping stems in distilled water. Fresh biomass and quality of floral stems were determined every other day. Silver thiosulphate applied in pulsing for 60 minutes or more led to stem dehydration, whereas calcium sulphate improved both stem hydration and commercial durability.
\end{abstract}

Keywords: Alpinia purpurata, tropical flowers, commercial durability, cut flower, vase life.

\section{RESUMO}

Pós-colheita de hastes de alpínia tratadas com tiossulfato de prata, sacarose e cálcio

O mercado brasileiro de flores tropicais encontra-se em franco crescimento, com uma importante participação da região Nordeste, destacando-se o estado de Alagoas. Dentre as flores tropicais de corte para exportação, a alpínia (Alpinia purpurata (Vieill) K. Schum) ocupa posição de destaque. Visando retardar a senescência das hastes florais de alpínia, cultivar Pink Ginger, foram conduzidos dois experimentos em laboratório no CCA da Universidade Federal de Alagoas. No primeiro, foram testados três tempos (30; 60 e 120 minutos) de exposição ao tiossulfato de prata $1 \mathrm{mM}$, seguido ou não de pulsing em sacarose a $20 \%$, por 12 horas. No segundo experimento foram verificados os efeitos nas relações hídricas e longevidade das hastes da adição de sulfato de cálcio a 50 e $100 \mathrm{mM}$, silicato de sódio a 1,25 e 2,50 mM, além da interação sulfato de cálcio a $50 \mathrm{mM}+$ silicato de sódio a 1,25 mM, em solução de manutenção. Nos dois experimentos, a testemunha consistiu da manutenção das hastes em água destilada. A massa fresca e a qualidade das hastes foram determinadas a cada dois dias. O tiossulfato de prata, aplicado na forma de pulsing por 60 minutos ou mais, promoveu desidratação das hastes. O uso de sulfato de cálcio promoveu aumento da durabilidade comercial e melhoria da hidratação das hastes.

Palavras-chave: Alpinia purpurata, flores tropicais, durabilidade comercial, flor de corte, vida de vaso.

\section{(Recebido para publicação em 17 de setembro de 2008; aceito em 23 de junho de 2009)}

(Received in September 17, 2008; accepted in June 23, 2009)

\begin{abstract}
$A$ lpinia purpurata (Vieill) K. Schum. (Zingiberaceae) is an ornamental plant also used as a cut flower (Luz et al., 2005). Known as pink ginger, the plant originated from the forests and fields of New Caledonia, Salomon, and Virgin Islands, and Bismarck and Bougainville archipelagos (Wagner et al., 1999). Nowadays, the pink ginger can be found in different tropical regions around the world. It is ranked as the second most important tropical cut flower species in economic terms within the world market (Castán-Bañeras, 1997), as well as among the tropical flowers exported by the State of Alagoas.
\end{abstract}

The excessive loss of water by transpiration is one of the reasons for post harvest senescence (Paiva et al., 2005). High level of tissue hydration is usually associated to the increase of vase life in cut flowers, whereas fresh weight losses of 10 to $15 \%$ can cause tissue death (Moraes et al., 1999). The supply of different types of sugar, mainly sucrose, in conditioning or maintenance solutions, besides replacing the carbohydrates consumed by respiration, promotes reduction in transpiration, once it induces the closing of stomata (Halevy \& Mayak, 1981).

The wilting and senescence of cut flowers are influenced by ethylene (Finger et al., 1999). The silver ion is a competitive inhibitor, which reduces the binding of ethylene to its receptor (Cook \& Standen, 1987), preventing the hormone from acting and, consequently, increasing the longevity of cut flowers. The main use of silver in flower post harvest is as silver thiosulphate (STS). In red ginger, STS was tested by Broschat \& Donselman (1988), Reid (1989), and Mattiuz (2003). In all cases, phytotoxic effects were observed. However, once concentration and exposure time are important elements (Faragher et al., 2002), it is necessary to have these 
aspects tested, particularly for pink ginger.

Savvas et al. (2002) noticed that silicon ( $\mathrm{Si}$ ) in hydroponic solution improved stem quality in Gerbera jamesonii Bollus. Its use in postharvest demands investigation, once it reduces transpiration and increases xylem resistance to compression (Salisbury \& Ross, 1994). On the other hand, calcium, which has been broadly tested in fruit postharvest, started to be studied in flowers as well, with excellent results in roses (Torre et al., 1999; Capdeville et al., 2003, 2005).

The objective of this study was to test STS effects, followed or not by sucrose pulsing, as well as calcium and silicon use in the maintenance solution on the hydric status, and vase life of Alpinia purpurata var. Pink Ginger.

\section{MATERIAL AND METHODS}

This study consisted of two experiments carried out at the Laboratory of Vegetal Physiology from the CCA of the Universidade Federal de Alagoas, from June to August, 2005. Floral stems came from a commercial garden in the City of Rio Largo, Alagoas State. The two harvests were carried out by $7 \mathrm{~h} 00$ am. It took approximately 40 minutes to have the stems cut, prepared, and transported to the lab.

Harvested stems, having 20-cm long inflorescences and $2 / 3$ of their expanded bracts, were standardized $(90$ $\mathrm{cm}$ long, from the flower stem base to the inflorescence top), disinfested for 5 min in tanks filled with a solution of diazenon, decis and mineral oil in a proportion of $1 \mathrm{~mL} / \mathrm{L}$, rinsed in running water, and taken to the lab. Before setting up each experiment, stems were weighed in digital scales to determine initial fresh weight.

In the first experiment, stems were immersed in a silver thiosulphate solution (STS) $1 \mathrm{mM}$ for 30; 60; or 120 minutes, followed or not by pulsing in a sucrose solution $20 \%$ for $12 \mathrm{~h}$. Next, stems were transferred to recipients with distilled water where they were kept until the end of the experiment. In the second experiment, stems were kept in solutions of calcium sulphate (50 and $100 \mathrm{mM})$, or sodium silicate $(1,25$ and $2,5 \mathrm{mM}$ ), or in calcium sulphate $50 \mathrm{mM}$ + sodium silicate 1,25 mM. The first and second experiments summed up respectively seven and six treatments. Both experiments were carried out with four three-stem replications. The control treatment corresponded to stems kept in distilled water during the whole period.

In both experiments, stems were weighed and had their quality evaluated every other day. Three different evaluators graded stems according to the following criteria: (adapted from Tagliacozzo et al., 2003): 4= excellent (turgid and bright bracts); $3=$ good (start of turgor loss, only perceptible by touch); $2=$ moderate (visible turgor loss, stems bending up to $45^{\circ}$, leaf roll); $1=$ severe (severe turgor loss, stems bending more than $45^{\circ}$, most of leaves yellow and/or dry); and $0=$ very severe (flower stem totally dry). Simultaneously, stems were weighed to estimate the variation in fresh matter. The commercial durability was set as the number of days from harvest until stems reached an average grade of 2.7 (according to Tagliacozzo et al., 2003), while total longevity corresponded to the number of days from harvest to complete stem senescence (score 0).
Throughout the experiments, lab temperature was $24 \pm 1^{\circ} \mathrm{C}$, relative humidity $57 \pm 2 \%$, and light intensity 23,12 $\mu \mathrm{mol} \mathrm{m} \mathrm{m}^{-2} \mathrm{~s}^{-1}$. The experiments were carried out in a completely randomized design. Data were submitted to analyses of variance and $\mathrm{F}$ test. Means were compared using the Tukey test, at 5\% probability. Data corresponding to the fresh weight loss of floral stems during the period of longevity evaluation were submitted to analyses of regression.

\section{RESULTS AND DISCUSSION}

Stems pre treated with STS for 30 minutes and kept in distilled water presented the largest fresh weight throughout the experiment (Figure 1), which indicates that this treatment helped in preserving stem hydration. Nevertheless, there was no statistically significant effect of STS over the commercial durability and total longevity of stems when compared to the control (Table 1). Fresh weight loss was higher in stems submitted to STS + sucrose, showing that sucrose pulsing after the exposure to STS was harmful to stems. Symptoms of hydric deficiency, such as leaf roll, inflorescence bending, and dry up of bracts from the edges to the center, were occasionally observed, mostly in treatments with STS for 120

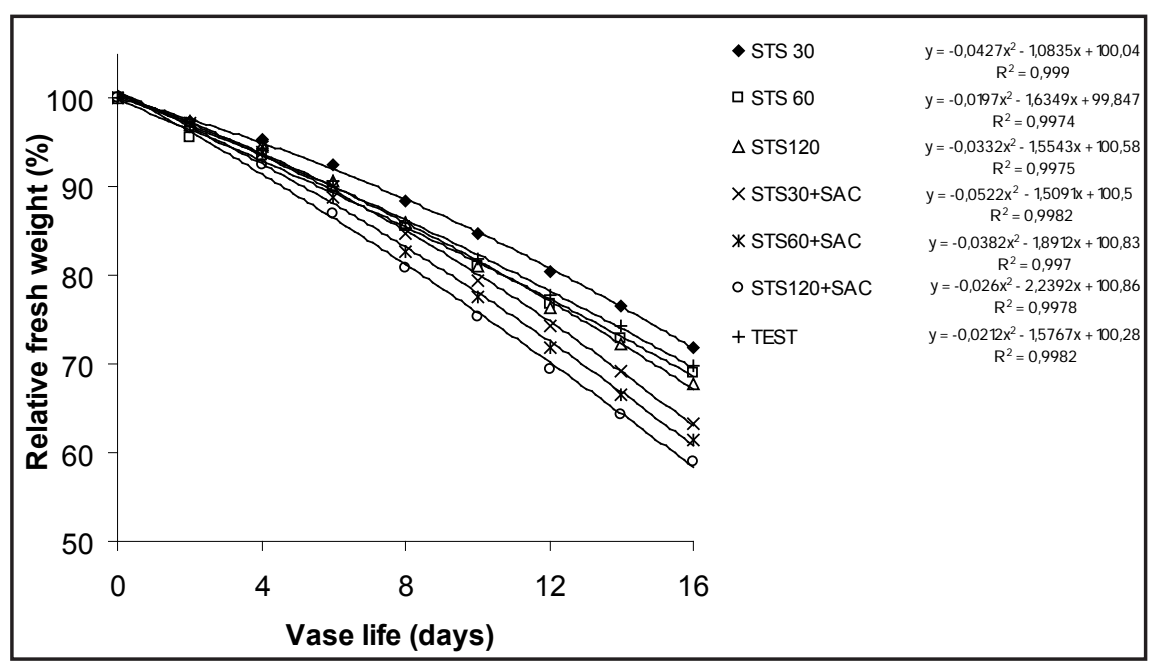

Figure 1. Relative fresh weight of Pink Ginger stems submitted to silver thiossulphate (STS) $1 \mathrm{mM}$, for $30 ; 60$, and 120 minutes, followed or not by pulsing of sucrose $20 \%$ for 12 hours (massa fresca relativa de hastes de alpínia submetidas a solução de tiossulfato de prata (STS) a $1 \mathrm{mM}$, por 30; 60 e 120 minutos, seguidas ou não de pulsing de sacarose, a 20\%, por 12 horas). Rio Largo, UFAL, 2009. 
Table 1. Commercial durability and total longevity of Pink Ginger stems submitted to silver thiossulphate $1 \mathrm{mM}$, for $30 ; 60$, and 120 minutes, followed or not by a pulsing of sacharose $20 \%$ for 12 hours (durabilidade comercial e longevidade total de hastes de alpínia submetidas à solução de tiossulfato de prata a 1mM, por 30; 60 e 120 minutos, seguido ou não de exposição a pulsing de sacarose a 20\%, por 12 horas). Rio Largo, UFAL, 2009.

\begin{tabular}{lcc}
\hline Treatments & $\begin{array}{c}\text { Commercial } \\
\text { durability (days) }\end{array}$ & $\begin{array}{c}\text { Total longevity } \\
\text { (days) }\end{array}$ \\
\hline $\mathrm{STS}^{1}$ for $30 \mathrm{~min}$ & $8,2 \mathrm{~A}$ & $16,0 \mathrm{~A}$ \\
$\mathrm{STS}^{1}$ for $60 \mathrm{~min}$ & $6,5 \mathrm{~A}$ & $15,5 \mathrm{AB}$ \\
$\mathrm{STS}^{1}$ for $120 \mathrm{~min}$ & $6,0 \mathrm{~A}$ & $15,0 \mathrm{AB}$ \\
$\mathrm{STS}^{1}$ for $30 \mathrm{~min}+$ sucrose for $12 \mathrm{~h}$ & $5,5 \mathrm{~A}$ & $15,0 \mathrm{AB}$ \\
$\mathrm{STS}^{1}$ for $60 \mathrm{~min}+$ sucrose for $12 \mathrm{~h}$ & $5,0 \mathrm{~A}$ & $16,0 \mathrm{~A}$ \\
$\mathrm{STS}^{1}$ for $120 \mathrm{~min}+$ sucrose for $12 \mathrm{~h}$ & $4,7 \mathrm{~A}$ & $12,5 \mathrm{~B}$ \\
$\mathrm{Control}$ & $6,2 \mathrm{~A}$ & $15,5 \mathrm{~A}$ \\
\hline CV $\%$ & $\mathbf{3 5 , 8}$ & $\mathbf{9 , 3}$ \\
\hline
\end{tabular}

Means followed by the same letter in the column do not differ significantly from each other, Tukey test, $\mathrm{p}<0.05$ (médias seguidas de mesma letra na coluna não diferem significativamente entre si, Teste de Tukey, $\mathrm{p}<0,05)$; ${ }^{1} \mathrm{STS}=$ silver thiosulphate (tiossulfato de prata).

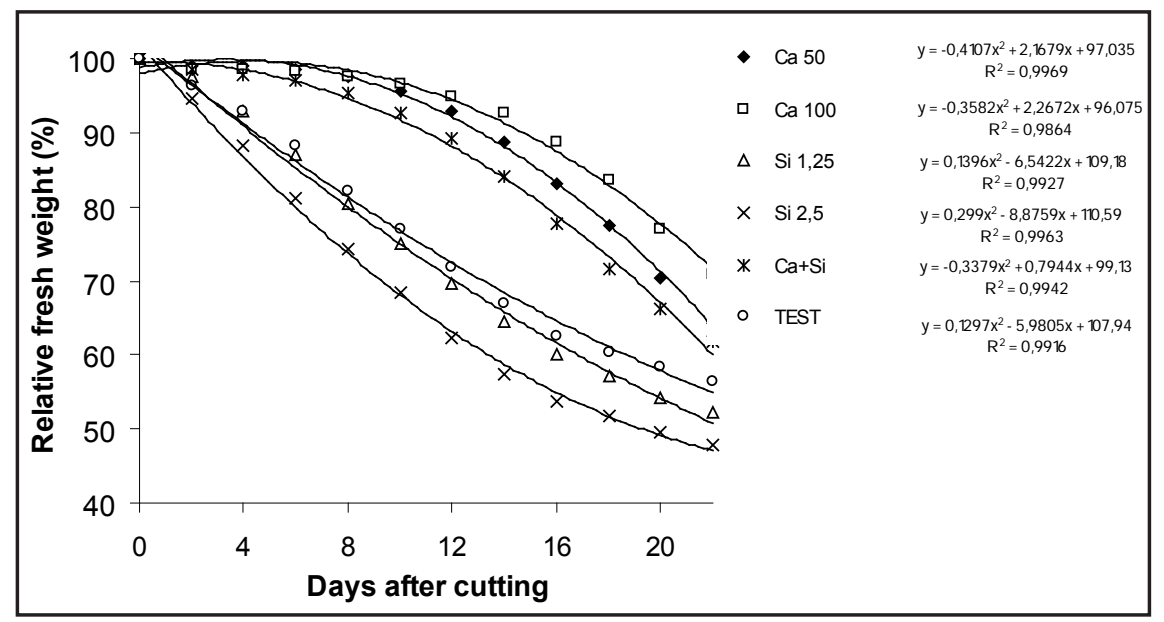

Figure 2. Relative fresh weight of Pink Ginger stems kept in different vase solutions, containing calcium sulphate 50 and $100 \mathrm{mM}$, sodium 1,25 and $2,5 \mathrm{mM}$, and calcium sulphate $50 \mathrm{mM}+$ sodium silicate $1,25 \mathrm{mM}$ (massa fresca relativa de hastes de alpínia mantidas em diferentes soluções de manutenção, contendo sulfato de cálcio a 50 e $100 \mathrm{mM}$, silicato de sódio a 1,25 e 2,5 mM e sulfato de cálcio a $50 \mathrm{mM}+$ silicato de sódio a 1,25 mM). Rio Largo, UFAL, 2009.

minutes + sucrose for $12 \mathrm{~h}$. In addition, leaf whitening, which is typical of STS phytotoxicity (Faragher et al., 2002), was also present. In Alpinia purpurata, cultivar Red Ginger, Broschat \& Donselman (1988), and Mattiuz (2003) found phytotoxic effects when STS $2 \mathrm{mM}$ and $1 \mathrm{mM}$ were applied with pulsing for 4 and 6 hours respectively. The results gathered in the present study suggest that STS $1 \mathrm{mM}$ for 30 minutes approached the limit between the sought benefit and the toxic effect, in a vase solution with sucrose $2 \%+$ citrate of hydroxiquinoline $200 \mathrm{ppm}$ or in deionized water. In both cases, a drastic reduction in the post harvest life due to the phytotoxic effects was observed. Likewise, Finger et al. (2004), after working with Consolida ajacis Nieuw, noticed that stems treated only with STS $1 \mathrm{mM}$ for 30 minutes had a larger longevity than those treated with STS $1 \mathrm{mM}+$ sucrose $5 \%$ for 30 minutes, which, according to the authors, was due to the autocatalytic stimulation of the ethylene by sucrose.

In the second experiment, treatments using calcium sulphate improved stem hydration and preserved the stem fresh weight up to the eighth day (Figure 2). On contrary, the hydration level in treatments with sodium silicate was below those observed in the control. Calcium sulphate significantly extended both the commercial durability and the total longevity of stems (Table 2). Sodium silicate results, when used alone, independent of the concentration, were similar or worse than those of the control. The use of calcium sulphate + sodium silicate did not differ significantly from treatments in which only calcium sulphate was employed.

Calcium sulphate positive effects can be credited to the ion calcium, once this element has presented remarkable effects in stomata closure, a mechanism that regulates water stress (Yang et al., 2003; Taiz \& Zeiger, 2004). Furthermore, high concentrations of calcium in vegetal tissues reduce both the ethylene production and the transpiration level. Calcium role is comparable to AVG's (aminoethoxy vinyl glycine, an inhibitor of the enzyme ACC sintase), inhibiting the ethylene synthesis, and also similar to cytocinines' in suppressing respiration, which suggests that calcium may have a role as a hormone regulator in senescent tissues (Fernandes, 2002). In Pink Ginger, ion $\mathrm{Ca}^{2+}$ behaved as a senescence delayer in vase life, probably by regulating the water stress, as well as preserving membrane functions and structure (Halevy et al., 2001), or making the cellular walls less accessible to the action of hydrolytic enzymes (Poovaiah et al., 1988).

In addition to calcium, we could 
Table 2. Commercial durability and total longevity of Pink Ginger stems kept in different vase solutions, containing calcium sulphate and/or sodium silicate (durabilidade comercial e longevidade total de hastes de alpínia mantidas em diferentes soluções de manutenção contendo sulfato de cálcio e/ou silicato de sódio). Rio Largo, UFAL, 2009.

\begin{tabular}{lcc}
\hline Treatments & $\begin{array}{c}\text { Commercial durability } \\
\text { (days) }\end{array}$ & $\begin{array}{c}\text { Total longevity } \\
\text { (days) }\end{array}$ \\
\hline Ca $100 \mathrm{mM}$ & $15,2 \mathrm{~A}$ & $21,0 \mathrm{~A}$ \\
$\mathrm{Ca} 50 \mathrm{mM}$ & $13,7 \mathrm{~A}$ & $21,5 \mathrm{~A}$ \\
Si $1,25 \mathrm{mM}$ & $5,5 \mathrm{~B}$ & $14,5 \mathrm{~B}$ \\
Si $2,5 \mathrm{mM}$ & $3,5 \mathrm{~B}$ & $11,0 \mathrm{~B}$ \\
Ca $50 \mathrm{mM}+\mathrm{Si} 1,25 \mathrm{mM}$ & $13,5 \mathrm{~A}$ & $21,0 \mathrm{~A}$ \\
Control & $5,5 \mathrm{~B}$ & $14,5 \mathrm{~B}$ \\
\hline CV $(\%)$ & $\mathbf{2 1 , 3}$ & $\mathbf{1 0 , 7}$ \\
\hline
\end{tabular}

Means followed by the same letter in the column do not differ significantly from each other, Tukey test, $\mathrm{p}<0.05$ (médias seguidas de mesma letra na coluna não diferem significativamente entre si, Teste de Tukey, $\mathrm{p}<0,05$ ).

have attributed some importance to sulphur as well. Nevertheless, it should be highlighted that sulphate $\left(\mathrm{SO}_{4}{ }^{2-}\right)$ is reduced by assimilation and that sulphete is the final product of this reaction. Sulphete does not accumulate in the cells and is quickly reduced to amino acids cysteine and methionine. The later copound is ethylene precursor (Taiz \& Zeiger, 2004).

Silicon was expected to present better results, especially regarding the stem hydric balance. Silicon reduces plant transpiration and increases xylem resistance to compression (Salisbury \& Ross, 1994), which decreases plant water demand (Korndörfer \& Pereira, 2001). However, this has not been confirmed. On contrary, it was observed that sodium silicate had deleterious effects, possibly due to the presence of sodium.

Sucrose and STS in the studied concentrations did not increase stem longevity, although it is suggested that tests with STS in lower concentrations should be carried out. Calcium sulphate had promising results regarding flower stem longevity in Pink Ginger. As far as we know, the results reported here in the use of calcium to extend vase life on tropical cut flowers are the first ever, and open a range of opportunities for future research using calcium solutions.

\section{ACKNOWLEDGEMENTS}

Authors thank FAPEAL (Fundação de apoio à pesquisa do estado de Alagoas) for sponsoring the Research Project and Prof. Dr. Eurico Eduardo Pinto Lemos for revising the Abstract. Érika SA Graciano and Renan C de Souza hold Scientific Initiation scholarships (IC), granted by FAPEAL.

\section{REFERENCES}

BROSCHAT TK; DONSELMAN H. 1988. Production and postharvest culture of red ginger in south Florida. Proceedings of Florida State Horticulture Society 101: 326-327.

CAPDEVILLE G; MAFFIA LA; FINGER FL; BATISTA UG. 2003. Gray mold severity and vase life of rose buds after pulsing with citric acid, salicylic acid, calcium sulfate, sucrose and silver thiosulfate. Fitopatologia Brasileira 28: 380-385.

CAPDEVILLE G; MAFFIA LA; FINGER FL; BATISTA UG. 2005. Pre-harvest calcium sulfate applications affect vase life and severity of gray mold in cut roses. Scientia Horticulturae 103: 329-338.

CASTÁN BAÑERAS J. 1997. Tecnologia em floricultura tropical. Revista Brasileira de Horticultura Ornamental 3: 5-9.

COOK EL; STANDEN J VAN. 1987. Silver action in the cut carnation flower. Plant Physiology and Biochemistry 25: 485-492.

CRAMER GR; LÄUCHLI A; POLITO VS. 1985. Displacement of $\mathrm{Ca}^{2+}$ by $\mathrm{Na}^{+}$from the plasmalemma of root cells. Plant Physiology 79: 207-211.

FARAGHER J; SLATER T; JOYCE D; WILLIAMSON V. 2002. Postharvest handling of Australian flowers - from Australian native plants and related species: a pratical workbook. Victoria: RIRDC. 215p.

FERNANDES RR. 2002. Fisiologia pós-colheita de espécies olerícolas. In: WACHOWICZ CM; CARVALHO RIN (eds.) Fisiologia vegetal: produção e pós-colheita. Curitiba: Champagnat. p.315-358.

FINGER FL; CAMPANHA MM; BARBOSA JG; FONTES PCR. 1999. Influence of ethephon, silver thiosulfate and sucrose pulsing on birdof-paradise vase life. Revista Brasileira de Fisiologia Vegetal 11: 119-122.

FINGER FL; CARNEIRO TF; BARBOSA JG. 2004. Senescência pós-colheita de inflorescências de esporinha. Pesquisa Agropecuária Brasileira 39: 533-537.

HALEVY AH; TORRE S; BOROCHOV A; PORAT R; PHILOSOPH-HADAS S; MEIR S; FRIEDMAN H. 2001. Calcium in regulation of postharvest life of flowers. Acta Horticulturae 543: 345-351.

HALEVYAH; MAYAK S. 1981. Senescence and postharvest physiology of cut flowers - part 2. In: JANICK J. (ed.) Horticultural Reviews. Westpost: AVI Publishing 3: 59-143.

ICHIMURA K; HIRAIA T. 1999. Effects of silver tiosulfate complex (STS) in combination with sucrose on the vase life of cut sweet pea flowers. Journal of the Japanese Society for Horticultural Science 68: 23-27.

KORNDÖRFER GH; PEREIRA HS. 2001. O papel do silício na citricultura. Citricultura Atual 4: 16-18.

LIAO L; LIN Y; HUANG K; CHEN W; CHENG Y. 2000. Postharvest life of cut rose flower as affected by silver thiosulfate and sucrose. Botanical Bulletin of Academia Sinica 41: 299-303.

LUZ PB; ALMEIDAEFA; PAIVAPDO; RIBEIRO TR. 2005. Cultivo de flores tropicais. Informe Agropecuário 26: 62-72.

MATTIUZ CFM. 2003. Fisiologia Pós-colheita de Inflorescência de Alpinia purpurata (Vieill) K. Schum. Jaboticabal: UNESP FCAV. 124p (Tese doutorado).

MORAES PJ; CECON PR; FINGER FL; BARBOSA JG; ALVARES VS. 1999. Efeito da refrigeração e do condicionamento em sacarose sobre a longevidade de inflorescências de Strelitzia reginae Ait. Revista Brasileira de Horticultura Ornamental 5: 151-156.

PAIVA R; OLIVEIRA LM; NOGUEIRA RC; SANTOS BR; MARTINOTTO C; PAIVA PDO; MENEGUCCI JLP. 2005. Aspectos fisiológicos da produção de flores e plantas ornamentais. Informe Agropecuário 26: 12-18.

POOVAIAH BW. 1988. Molecular and cellular aspects of calcium action in plants. HortScience 23: 267-271.

REID MS. 1989. The role of ethylene in flower senescence. Acta Horticulturae 261: 157169.

SALISBURY FB; ROSS CW. 1994. Fisiología vegetal. Ciudad del México: Grupo Editorial Iberoamérica. 710p.

SAVVAS D; MANOS G; KOTSIRAS A; SOUVALIOTIS S. 2002. Effects of silicon and nutrient-induced salinity on yield, flower quality and nutrient uptake of gerbera grown in a closed hydroponic system. Journal of Applied Botany 76: 153-158.

TAGLIACOZZO GMD; CASTRO CEF. 2002. Fisiologia pós-colheita de espécies ornamentais. 
Post harvest of pink ginger floral stems treated with silver thiosulphate, sucrose, and calcium

In: WACHOWICZ CM; CARVALHO RIN (eds.) Fisiologia vegetal: produção e póscolheita. Curitiba: Champagnat, p.359-382.

TAGLIACOZZO GMD; ZULLO MA; CASTRO CEF. 2003. Caracterização física e conservação pós-colheita de alpínia. Revista Brasileira de Horticultura Ornamental 9:17-23.
TAIZ L; ZEIGER E. 2004. Fisiologia Vegetal. Porto Alegre: Artmed. 719p.

TORRE S; BOROCHOV A; HALEVY AH. 1999. Calcium regulation of senescence in rose petals. Physiologia Plantarum 107: 214-222.

WAGNER WL; HERBST DR; SOHMER SH. 1999. Manual of the flowering plants of
Hawaii. Honolulu: University of Hawaii Press. 1618p.

YANG H-M; ZHANG X-Y; WANG G-X; LI Y; WEI X-P. 2003. Cytosolic calcium oscillation may induce stomatal oscillation in Vicia faba. Plant Science 65: 1117-1122. 